these qualities both by direct measurement and by means of gauges are in need of some revision". The paper underlines some of the difficulties and fallacies concerned with the present technique and suggests means to overcome them. His conclusions may be summarized as follows: (1) "Confusion over which directions through a particle should be measured in order to ascertain the long $(a)$, intermediate $(b)$ and short $(c)$ diameters can be resolved by taking the actual longest axis as $a$, the axis determining the smallest circular (or square) aperture through which the particle could pass as $b$ and the axis determining the narrowest slot through which the particle could pass as $c$. The long, intermediate and short diamoters are not necessarily at right angles to each other"; (2) "Present British Standard flakiness and elongation gauges do not satisfactorily perform the function for which they wore intended"; (3) it is considered that calliper measurements are the most accurate means of assessing fitness and elongation ratios, and that even judgment by eye, where trained observers are employed, is superior to the use of gauges in classifying particles into shape categories; (4) finally, it is recommended that a return be made to Zingg's ratio of 0.66 for both elongation and flatness ratio boundaries between shape categories. This paper appears at a time when the revision of British Standard 812: 1960, Methods for Sampling and Testing of Mineral Aggregates, Sands and Fillers, is approaching completion, and doubtless its import will not be overlooked.

Introduction of Cash Flow into Critical Path Scheduling

A. C. Kleinschmidt, W. R. Moore and V. M. Tamashunas of the Industrial Engineering Department, Iowa State University, Ames, Iowa, have recently completed an investigation to determine whether components should be manufactured in the user's plant rather than purchased (Int. J. Prod. Res., 3, No. 2; 1964). The critical path technique was of assistance in developing a general-purpose model for 'produce' or 'purchase' decisions, in conjunction with a 'requirements planning network'. Though the pre-planning activities shown are often quite informally determined, the use of the network contributes valuable information to production planners. The purpose of a production plan is to provide management with information and recommendations necessary for an intelligent decision. Company managements have operated effectively during past years with the conventional summaries showing project costs and proposed savings. The timing of expenditures and close control of the completion date, however, are of more importance each succeeding year. The use of the critical path technique makes it possible to show this information in the analysis summary report which is submitted to management for approval. Through the mechanism of earliest starts and latest finishes, specific data concerning each major activity can be shown in a pre-production cash-flow analysis. In the test plan used as an example, real data on a present-day problem are shown. When an analysis is developed informally, unless immediate approval is given, the analysis is of little value. Formal preparation and recording of the different steps in completing analyses, together with the 'floating date' aspect of the critical path technique, permit the analysis to be delayed without penalty. When a plan needs to be delayed to await a more favourable time for action, the necessary information is readily available for roviow and quick action at any time. A form has been developed to standardize the record of the activity information developed in the plan.

\section{The Geological Society of London : Officers}

THE following have been elected officers of the Geological Society of London for the session 1965-66: President, Prof. F. W. Shotton, professor of geology, University of Birmingham; Vice-presidents, Prof. O. M. B. Bulman, Woodwardian professor of geology, University of Cambridge, Prof. L. Hawkes, emeritus professor of geology,
University of London, Prof. F. H. Stewart, Regius professor of geology, University of Edinburgh, and Prof. D. Williams, professor of mining geology, Imperial College of Science and Technology, University of London; Secretaries, Dr. P. A. Sabine, chief petrographer, Geological Survey and Museum, and Mr. W. B. Harland, University lecturer in geology, University of Cambridge; Foreign Secretary, Prof. O. M. B. Bulman; Treasurer, Dr. W. Bullerwell, chief geophysicist, Geological Survey and Museum.

\section{Announcements}

DR. P. R. Gross, at present associate professor of biology at Brown University, Providence, Rhode Island, has been appointed professor of biology at the Massachusetts Institute of Technology, where his research will be primarily concerned with growth and development at the molecular level.

Dr. F. Hartlex, Dean of the School of Pharmacy in the University of London and formerly director of research and scientific services at British Drug Houses, Ltd., has succeeded Prof. H. J. Eméléus as president of the Royal Institute of Chemistry and will hold office for the two years to April 1967. Dr. Hartley is a leading authority on drugs and is a member of the Dunlop Committee on the Safety of Drugs and vice-chairman of the British Pharmacopoeia Commission of the General Medical Council.

The British Tissue Culture Association has changed its name to the British Society for Cell Biology, as was decided at the annual general meeting held at Aberystwyth on April 3.

THE sixth international Radiocarbon Dating Conference will be held at Washington State University, Pullman, during June 7-11. Further information can be obtained from Dr. R. M. Chatters, Washington State University, Pullman, Washington.

The fifth Australian Spectroscopy Conference, sponsored by the Australian Academy of Sciences, will be held in Perth during May 31-June 2. Further information. can be obtained from Dr. A. J. Parker, Department of Chemistry, University of Western Australia, Nedlands.

The fifteenth annual meeting of the Soeiété de Chimie Physique, on "Movements and Phase Changes in Molecular Solids", will be held in Paris during May 31-June 4. Further information can be obtained from Prof. G. Emschwiller, Société de Chimie Physique, 10 rue Vauquelin, Paris 5.

The forty-eighth Canadian chemical conference, on "Chemistry-Formula for Progress", and exhibition of the Chemical Institute of Canada will be held in Montreal during May 31-June 2. Further information can be obtained from the Chemical Institute of Canada, 48 Rideau Street, Ottawa 2, Ontario.

A symposium on "Genetic Control of Differentiation", arranged by the Biological Department of Brookhaven National Laboratory, will be held at the Laboratory during June 7-9. Further information can be obtained from Dr. H. H. Smith, Brookhaven National Laboratory, Upton, Long Island, New York.

CORRIGENDUM. In the article "Nature of Electron Equilibrium in Heterogeneous Solids and the Proposed Electron Energy Distribution in Degenerate $p-n$ Junc. tions" by Prof. M. A. Melehy, which appears on p. 456 of the January 30 issue of Nature, on the left-hand side of equation (44), the quantity $\psi$ should be replaced by $(\psi / q)$. Also in the second paragraph preceding equation (44) the two consecutive sentences pertaining to the battery voltage should read: "Here $(v / q)$ is the forward applied voltage. This change in ..., the electron gains $(v / q)$ electron volts from the battery". In the M.K.s., the units of $(\psi, q)$ and $(v, q)$ are in volts, while $\psi$, and $v$ would have the same unit as $k T$. 